\title{
Capability in Utilizing Social Media as a Promotion Strategy for Increasing the UMKM Economy
}

\section{Kapabilitas dalam Pemanfaatan Media Sosial Sebagai Strategi Promosi Bagi Peningkatan Perekonomian UMKM}

\author{
Lucky Destianah \\ Universitas Jember \\ Email: luckydestiana12345@gmail.com
}

\begin{abstract}
The business world in Indonesian is now expanding, including UMKM. A lot of MSMEs in Indonesian today can be used to support the country's economy. Especially is it supported by the growing information technology. They include social media such as facebook, whatsapp, instagram, and the like, which can be used as promotional media for businesses. The fact is that micro business leaders lack the optimum understanding and optimally utilizing technology, which suggests that they lack the ability to read the business opportunities. If they can harness the technology optimally then surely the profit they get is absolute. Furthermore, people are more likely to know their business because of the unlimited social media reach, making it easier to be known to the public. From the data I've obtained, micro businesses are underulitizing the sophistication of current technology, especially for those who are old and have little knowledge. Then, the majority of women in business can not give much attention to their business because their something higher priority, such as family. As we know it is only natural for a women to take care of the household so that there is a gap between the male and the female. It is these gaps that prevent the use of information technology in the economic growth of MSMEs.
\end{abstract}

Keyword: Inequality, Use Of Social Media, Marketing Strategies, Msmes Economic Growth.

\begin{abstract}
ABSTRAK
Dunia bisnis di Indonesia saat ini semakin berkembang, termasuk UMKM. Banyaknya UMKM di Indonesia saat ini dapat dimanfaatkan untuk menunjang perekonomian negara. Apalagi didukung dengan adanya teknologi informasi yang semakin berkembang. Teknologi informasi yang dimaksud yaitu media sosial seperti facebook, whatsapp, instagram, dan semacamnya yang dapat dimanfaatkan sebagai media promosi bagi pelaku bisnis. Namun faktanya, para pelaku bisnis mikro kurang memahami dan memanfaatkan teknologi secara optimal, ini menggambarkan bahwa mereka kurang mampu untuk membaca peluang usaha. Jika mereka dapat memanfaatkan teknologi secara optimal maka dapat dipastikan keuntungan yang mereka peroleh bersifat mutlak. Selain itu, orang akan lebih mudah mengetahui bisnis mereka karena jangkauan sosial media yang tidak terbatas, sehingga akan lebih mudah dikenal oleh khalayak umum. Dari data yang saya peroleh menyatakan bahwa para pelaku usaha mikro kurang memanfaatkan kecanggihan teknologi saat ini, khususnya bagi mereka yang sudah berumur dan memiliki pengetahuan yang minim. Kemudian, sebagian besar pelaku usaha perempuan tidak bisa secara penuh mencurahkan perhatiannya kepada bisnisnya karena terdapat hal lain yang lebih diprioritaskan, seperti keluarga. Seperti yang kita tahu bahwa sudah menjadi kodrat wanita untuk mengurus rumah tangga sehingga terdapat gap antara laki-laki dan perempuan. Adanya kesenjangan-kesenjangan inilah yang menghambat pemanfaatan teknologi informasi dalam meningkatkan perekonomian UMKM.
\end{abstract}

Kata Kunci: Kesenjangan, Pemanfaatan Sosial Media, Strategi Pemasaran, Pertumbuhan Perekonomian UMKM. 


\section{PENDAHULUAN}

Pertumbuhan perekonomian Indonesia saat ini mencapai 5,05\% setelah mengalami resesi sebesar 4,19\% pada triwulan sebelumnya yang sebagian besar disebabkan karena adanya pandemi covid-19. Merosotnya perekonomian Indonesia mengakibatkan banyaknya jumlah PHK sehingga angka pengangguran meningkat. Dari sini banyak masyarakat yang beralih menjadi pelaku bisnis mikro, khususnya dalam ranah online. Berkembangnya teknologi informasi berdampak pada adanya perubahan sosial di lingkungan masyarakat, terutama dibidang bisnis. Dimana jika sebelumnya proses bisnis hanya bisa dijalankan secara offline, namun setelah berkembangnya teknologi informasi seperti sosial media, kegiatan bisnis dapat dijalankan secara offline dan online. Jangkauan sosial media yang tidak terbatas memungkinkan para pelaku bisnis untuk menyebarluaskan produknya. Tidak heran jika suatu produk bisnis akan lebih mudah dikenal oleh masyarakat luas sehingga sangat membantu dalam proses berkembangnya suatu usaha.

Namun faktanya, masih sedikit pelaku usaha mikro yang memanfaatkan media sosial sebagai salah satu sarana untuk memasarkan produknya. Apalagi di daerah pedesaan yang masih minim pengetahuan terkait teknologi. Fasilitas di daerah pedesaan yang kurang memadai dapat menjadi faktor penting sebagai penyebab terjadinya kesenjangan dalam pemanfaatan sosial media sebagai salah satu strategi pemasaran. Notabene kualitas penduduk di daerah pedesaan masih sangat rendah karena minimnya pendidikan. Sehingga membutuhkan waktu lama bagi masyarakat desa agar dapat menyamai kemampuan masyarakat kota yang pada umumnya sudah menguasai teknologi. Umur juga menjadi faktor penting yang mempengaruhi proses belajar untuk memanfaatkan penggunaan teknologi informasi dalam mengonstruksi jalannya bisnis. Selain itu, bagi para perempuan yang sudah disibukkan dengan permasalahan rumah tangga tidak memiliki waktu untuk belajar menguasai teknologi yang telah tersedia. Mereka terlalu sibuk untuk mengurus rumah tangganya, apalagi bagi mereka yang memiliki balita. Sebagian besar ibu rumah tangga yang menjalankan bisnis tidak sepenuhnya terjun ke bidang tersebut, mereka hanya menjadikan bisnis sebagai prioritas ke dua, dimana hal ini hanya untuk mengalihkan rasa jenuh dari kesibukan yang biasa dilakukan oleh ibu- ibu rumah tangga lainnya. Meskipun terdapat beberapa perempuan yang serius dalam menjalankan bisnis, namun jika dibandingkan dengan laki-laki tingkat keseriusannnya akan berbeda. Pada umumnya, mereka takut untuk menyelam lebih dalam, ketakutan inilah yang membuat mereka tetap berada di zona nyaman.

Dengan kecanggihan teknologi yang disuguhkan saat ini, seharusnya dapat dimanfaatkan secara maksimal oleh para pelaku bisnis dalam meningkat profit penjualan. Pada dasarnya, teknologi diciptakan untuk mempermudah kehidupan manusia sehingga aneh rasanya jika kita sebagai manusia yang sudah diberikan kemudahan namun tidak mau belajar menggunakannya. Kemajuan teknologi merupakan sesuatu yang tidak bisa dihindari saat ini, sehingga mau tidak mau kita harus berusaha untuk menyesuaikan diri dengan perubahan atau kita akan tertinggal. Dengan adanya kemajuan teknologi ini tercipta inovasi- inovasi baru dalam kehidupan manusia, terutama dalam sektor bisnis. Faktanya, para pengusaha terutama yang tergolong memiliki umur yang matang tidak memanfaatkan teknologi secara maksimal karena adanya kesenjangan-kesenjangan sosial. Mereka belum menyadari betapa pentingnya teknologi informasi dalam meningkatkan perekonomian. Apalagi para pengusaha mikro yang tidak memiliki pendapatan besar jika dibanding dengan pengusaha-pengusaha bisnis besar. Seharusnya para pelaku usaha berskala mikro dapat memanfaatkan teknologi untuk mendongkrak perekonomian Usaha Mikro, Kecil dan menengah (UMKM), berlaku bagi semua pengusaha, tidak hanya mereka yang masih berusia belia.

Setiap pengusaha tentu memiliki persepsi berbeda dalam mengoordinasikan usahanya. Dari penelitian ini, peneliti ingin mengkaji lebih dalam perspektif-perspektif para pelaku bisnis mikro dalam pemanfaatan teknologi informasi guna menunjang perekonomian UMKM. Berangkat dari adanya kesenjangan-kesenjangan yang menghambat pemanfaatan teknologi informasi sebagai salah satu tempat pemasaran berbasis digital.

\section{METODE PENELITIAN}

Penelitian ini menggunakan metode penelitian kualitatif. Menurut Strauss dan Corbin dalam Cresswell, J. (1998:24), penelitian kualitatif merupakan salah satu jenis penelitian yang menghasilkan penemuan-penemuan, dimana penemuan tersebut tidak bisa diperoleh melalui 
prosedur-prosedur statistik atau kuantitatif. Pemilihan jenis penelitian ini dianggap mampu untuk memberikan penjelasan terkait implementasi usia dalam pemanfaatan teknologi sebagai media promosi bagi pelaku usaha mikro. Penelitian ini dilakukan di daerah Kecamatan Ambulu, Kabupaten Jember. Penentuan lokasi ini karena pokok pembahasan atau tema yang diangkat oleh peneliti masih berlaku di daerah ini. Selan itu, adanya pandemi mengharuskan kita untuk berdiam diri di rumah sehingga peneliti menentukan tempat penelitian di sekitar lingkungannya. Peneliti merasa yakin bahwa lkasi ini mapu memberikan seluruh informasi yang dibutuhkan olehe peneliti. Penelitian ini dilaksanakan pada 3 oktober - 16 oktober 2020.

Teknik pengumpulan data dalam penelitian ini menggunakan teknik pengumpulan data primer dan teknik pengumpulan data sekunder. Dalam memperoleh data-data tersebut, peneliti menggunakan metode observasi, wawancara, dan dokumentasi. Observasi sebagai metode observasi merupakan teknik pengumpulan data melalui pengamatan maupun pencatatan secara langsung terhadap topik penelitian yang ingin dibahas. Pada hakikatnya, observasi merupakan kegiatan menggunakan pancaindera seperi penglihatan, pendengaran, dan penciuman. Observasi dilakukan untuk memperoleh informasi yang dibutuhkan untuk menjawab pertanyaan penelitian. Hasil observasi dapat berupa peristiwa, aktivitas, objek, perasaan emosi seseorang, suasana atau kondisi tertentu. Metode wawancara dalam teknik pengumpulan data dilakukan melalui komunikasi secara langsung antara peneliti dengan informan atau orang yang akan dimintai informasi. Peneliti akan mengajukan beberapa pertanyaan yang sudah disiapkan sebelumnya kepada informan untuk mendapatkan informasi. Pada dasarnya, wawancara dilakukan untuk memeperoleh informasi secara mendalam terkait isu- isu atau tema yang sedang diangkat menjadi kajian penelitian. Hasil wawancara bisa berbeda dengan informasi yang sudah didapatkan sebelumnya, karena wawancara merupakan proses pembuktian.

Metode dokumentasi dilakukan dengan pengumpulan data biasanya berupa catatan, buku, transkip, hingga berupa foto dari hasil selama penelitian. Teknik dokumentasi merupakan salah satu cara pengumpulan data yang menghasilkan catatan- catatan penting terkait masalah yang akan diteliti sehingga akan diperoleh data yang lengkap, sah, dan tidak hanya berdasarkan pada perkiraan semata. Hasil penelitian akan lebih kredibel jika didukung dengan dokumendokumen yang bersangkutan. Dalam menganalisis data yang diperoleh, peneliti mencoba untuk memahami secara mendalam informasi yang didapat dari masyarakat. Dengan begitu peneliti dapat menarik kesimpulan secara terperinci dan terstruktur dari data yang diperoleh. Teknik yang digunakan dalam menganalisa data yaitu teknik interaktif. Dalam teknik interaktif terdapat tiga komponen analisis yaitu reduksi data, penyajian data, dan penarikan kesimpulan.

\section{HASIL DAN PEMBAHASAN}

\section{Perkembangan Pertumbuhan Usaha Mikro, Kecil, dan Menengah (UMKM) di Indonesia.}

Menurut Undang- undang No. 20 Pasal 1 Tahun 2008 tentang Usaha Mikro, Kecil, dan Menengah (UMKM), pengertian UMKM adalah: i. Usaha Mikro adalah usaha produktif milik orang perorangan dan/ atau badan usaha perorangan yg memenuhi kriteria Usaha Mikro sebagaimana diatur dalam Undang- undang ini. ii. Usaha Kecil adalah usaha ekonomi produktif yang berdiri sendiri, yang dilakuka oleh orang perorangan atau badan usaha yang bukan merupakan anak perusahaan atau bukan cabang perusahaan yang dimiliki, dikuasai, atau menjadi bagian baik langsung amupun tidak langsung dari usaha menengah maupun usaha besar yang memenuhi kriteria Usaha Kecil sebagaimana dimaksud dalam Undang-undang ini.

iii. Usaha Menengah adalah usaha ekonomi produktif yang berdiri sendiri, yang dilakukan oleh orang perseoranganatau badan usaha yang bukan merupakan anak perusahaan atau cabang perusahaan yang dimiliki, dikuasai, atau menjadi bagian baik langsung maupun tidak langsung dengan Usaha Kecil atau usaha besar dengan jumlah kekayaan bersih atau hasil penjualan tahunan sebagaimana diatur dalam Undang- undang ini.

Indonesia pernah mengalami krisis ekonomi pada tahun 1997 hingga 1998, diawali dengan melemahnya nilai tukar rupiah terhadap dollar AS dan krisis moneter yang memicu terjadinya resesi di Indonesia. Kondisi seperti ini melumpuhkan perekonomian Indonesia. Bahkan usaha berskala besar pun tidak dapat berkutik pada situasi seperti ini, namun terdapat perbedaan dimana hanya sektor Usaha Mikro, Kecil, dan Menengah (UMKM) yang mampu bertahan. 
Dikonfirmasi oleh Data Badan Pusat Statistika, yang mencatat bahwa jumlah UMKm di Indonesia tidak mengalami penurunan, pasca krisis ekonomi, justru pertumbuhan UMKM di Indonesia mengalami peningkatan. Pada tahun 2012, tercatat jumlah UMKM yang tumbuh dan berkembang di Indonesia mencapai 56.539 .560 unit. Dari jumlah tersebut, dikonfirmasi lagi bahwa jumlah usaha mikro sebesar 56.534 .592 unit atau jika dipersentasekan sebesar 99,99\%. Sementara itu, tercatat usaha berskala besar yang berkembang di Indonesia hanya sebanyak 4.968 unit atau sekitar 0,01\%. Ini menggambarkan bahwa UMKM merupakan usaha yang produktif dan konsisten, serta mampu mendukung pertumbuhan ekonomi Indonesia, baik yang bersifat makro maupun mikro.

Dalam menjalankan usahanya, banyak rintangan dan hambatan yang harus dihadapi oleh para pengusaha UMKM. Hambatan yang dihadapi oleh para pengusaha UMKM dalam mengembangkan usahanya bersifat kompleks yang meliputi beberapa indikator, dimana setiap indikator tersebut saling berkaitan. Indikator- indikator yang dimaksud seperti kurangnya permodalan, kurangnya kemampuan dalam memanagement, serta terbatasnya pemasaran. Inilah yang mengakibatkan ruang gerak suatu usaha mikro bersifat stagnan, dan menjadi sempit atau terbatas. Oleh karena itu, sebagai bagian dari perekonomian bangsa dan untuk meningkatkan perekonomian negara, UMKM harus mampu bersaing dengan meningkatkan inovasi. Inovasi dan kreativitas harus dijadikan prioritas dalam menjalankan usaha karena berkaitan dengan daya tahan dan jangka waktu kekokohan suatu usaha, khususnya usaha mikro. Kunci utama dalam pengembangan usaha mikro di Indonesia adalah kesungguhan dan peran serta pemerintah dalam proses pembangunan pertumbuhan UMKM di Indonesia, tak lupa pula semangat untuk maju dari para pelaku UMKM.

Di Indonesia angka kemiskinan masih terbilang cukup tinggi jika dibandingkan dengan negara- negara tetangga. Sudah menjadi keharusan bagi Indonesia untuk belajar dari negara tetangga dalam aspek meningkatkan perekonomian guna menekan angka kemiskinan. Salah satu solusi yang dapat dilakukan oleh pemerintah yaitu dengan meningkatkan sektor perekonomian UMKM sebagai salah satu bentuk alternatif penanggulangan kemiskinan di Indonesia. Hal ini dapat ditempuh oleh pemerintah, tanpa takut menanggung resiko yang cukup besar karena sektor UMKM mempunyai potensi yang baik dalam ranah ini. Faktanya, dalam penyerapan ketenaga kerjaan, sektor UMKM memegang peranan penting karena konstribusinya yang cukup besar dalam menampung ketenaga kerjaan tersebut. Tercatat lebih dari 99,45\% tenaga kerja yang mampu diserap oleh sektor UMKM, dan tercatat pula sekitar 30\% sumbagan UMKM terhadap Produk Domestik Bruto atau PDB. Sehingga jika upaya pengembangan UMKM di Indonesia lebih di tingkatkan, maka dapat dipastikan lebih banyak lagi tenaga kerja yang diserap oleh UMKM, hal ini tentunya akan mengurangi tingkat pengangguran di Indonesia yang terbilang cukup tinggi. Dan pada akhirnya ini juga akan berdampak pada pengurangan angka kemiskinan, sehingga secara perlahan pengentasan kemiskinan di Indonesia akan terealisasikan. Program perberdayaan UMKM sebagai Aksi Pengentasan Kemiskinan sudah dicanangkan oleh Presiden Yudhoyono sejak tahun 2005. Terdapat empat jenis kegiatan pokok yang akan dilakukan yakni menumbuhkan iklim usahayng kondusif, mengembagkan sistem pendukung usaha, mengembangkan wirausaha dan keunggulan kompetitif, serta memberdayakan Usaha Mikro, Kecil, dan Menengah (UMKM).

Berdasarkan data dari Biro Perencanaan Kementerian Negara Koperasi dan UKM Republik Indonesia, pada tahun 2008, mencatat bahwa Usaha Kecil dan Menengah (UKM di Indonesia telah banyak memberikan konstribusinya terhadap Produk Domestik Bruto (PDB) nasional sebesar 55,56\%. Untuk meningkatkan daya saing, memperluas pasar hingga menguasai pasar, UMKM membutuhkan inovasi baru seperti memanfaatkan media sosial guna mengakomodasi proses bisnis UKM. Media sosial dapat dijadikan sebagai tumpuan untuk meningkatkan keuntungan, karena media sosial menyediakan akses yang tidak terbatas, media sosial dapat memberikan informasi secara cepat, luas, dan efisien. Sehingga akan berguna untuk meningkatkan interaksi antar bagian dalam sebuah organisasi, meningkatkan siklus pengelolaan pemesanan barang, dan sebagainya. Namun isu kritis yang seringkali dihadapi oleh para pelaku usaha berskala mikro yaitu terbatasnya dana dan minimnya kadabilitas dalam penggunaan teknologi informasi. 


\section{Implementasi Pemanfaatan Media Sosial sebagai Strategi Promosi UMKM di Indonesia}

Pesatnya perkembangan teknologi saat ini memberikan dampak menyeluruh pada setiap aspek kehidupan manusia. Di zaman yang serba modern ini, aktivitas kehidupan manusia semakin dipermudah dengan hadirnya teknologi. Teknologi dan manusia merupakan dua hal yang tidak dapat dipisahkan saat ini, dimana manusia tidak dapat hidup tanpa kehadiran teknologi dan teknologi akan lenyap jika manusia merasa sudah tidak membutuhkan teknologi untuk membantu setiap aktivitas kehidupannya. Sehingga jika ditarik garis besarnya, teknologi ada karena manusia, dan akan terus berkembang sesuai dengan kebutuhan manusia itu sendiri. Dunia digital diperkirakan akan menjadi pusat dari seluruh aktivitas manusia, tak terkecuali aktivitas bisnis. Teknologi informasi kini menyuguhkan smartphone yang sudah dilengkapi fiturfitur canggih yang akan memudahkan manusia untuk mengaksesnya. Pertumbuhan kepemilikan smartphone di indonesia juga semakin meningkat setiap tahunnya, dimana setiap smartphone memberikan kemudahan akses internet, perbaikan infrastruktur telekomunikasi dalam rangka peningkatan kualitas akses data, serta diluncurkannya layanan 4G. Apalagi saat ini sudah tersedia jaringan 5G yang sudah diterapkan dibeberapa negara maju, diperkirakan Indonesia juga akan menerapkan layanan $5 \mathrm{G}$ ini. Jaringan $5 \mathrm{G}$ diprediksi memiliki kecepatan hingga tiga kali lipat dari generasi sebelumnya.

Perkembangan teknologi informasi merubah sistem pemasaran. Dimana sebelum adanya internet dan media sosial, tren strategi pemasaran masih bersifat konvensional atau offline dimana sistem promosi dilakukan melalui majalah, koran, brosur, door to door, atau bahkan dari mulut ke mulut. Namun sekarang, dunia sudah berubah, dimana segala sesuatu dapat dilakukan melalui smartphone. Strategi promosi yang semula konvensional (Offline) berubah menjadi digital (online). Strategi promosi yang berbasis online sedang menjadi tren saat ini, bahkan sedang digeluti oleh berbagai lapisan masyarakat, dari muda hingga tua. Hal ini didasarkan pada potensial digital marketing yang lebih memudahkan calon pembeli untuk memperoleh segala informasi terkait barang yang diinginkan, proses pembayaran yang mudah juga menjadi daya tarik tersendiri untuk memikat calon pelanggan agar mengikuti tren belanja saat ini. Calon pelanggan dapat memesan dan melakukan transaksi hanya lewat telepon genggam yang ia miliki, tanpa harus keluar rumah. Oleh karena itu, banyak platform- platform belanja yang disediakan untuk memenuhi kebutuhan masyarakat modern.

Digital marketing merupakan kegiatan promosi dan pencarian pasar melalui media digital secara online dengan memanfaatkan berbagai sarana seperti jejaring sosial. Kini dunia maya mampu untuk menghubungkan orang dari segala penjuru dunia, hingga tercipta peribahasa "dunia hanya selebar daun kelor". Ini menggambarkan betapa mudahnya untuk bertukar informasi saat ini tanpa terhalang oleh jarak dan waktu. Teknologi mampu memudahkan pengusaha dalam memantau dan menyediakan segala kebutuhan dan keinginan calon konsumen, dan mampu memberikan akses kepada calon pembeli untuk mencari dan mendapatkan barang yang diinginkan hanya dengan menjelajahi platform marketplace. Teknologi telah mengubah cara hidup manusia mulai dari aspek berkomunikasi, bertindak, dan dalam pengambilan keputusan.

Menurut data yang dimuat oleh We are Social, yaitu sebuah agensi digital marketing di Amerika Serikat, mengkonfirmasi terkat platform media sosial yang paling bayak dikunjungi oleh masyarakat Indonesia per Januari 2017 yaitu Youtube sebanyak 49\%, dan Facebook sebanyak 48\%, kemudian Instagram sebanyak 39\%, Twitter 38\%, Whatsapp 38\%, Google sebanyak 36\%, yang kemudian sisanya diduduki oleh FB Messenger, Line, Linkedin, BBM, Pinterest, dan Wechat (Kemp, 2017). Ini menggambarkan perilaku masyarakat Indonesia yang semakin mengarah ke gaya hidup digital.

Terhitung pula sebanyak 48\% pengguna internet di Indonesia melakukan pencarian barang dan jasa secara online, sebanyak $46 \%$ pengguna internet mengunjungi toko online, kemudian $34 \%$ pengguna internet melakukan transaksi online melalui komputer atau laptop, dan sebanyak 33\% pengguna internet melakukan transaksi online melalui telepon genggam pribadi. Diperkirakan angka penggunaan internet di Indonesia akan terus meningkat setiap tahunnya, seiring dengan meningkatnya pengguna internet di Indonesia. Ini menjelaskan bahwa di Indonesia aktivitas belanja online sudah berkembang dan memiliki potensi, oleh karena itu 
harus diimbangi dengan strategi pemasaran digital oleh para pelaku usaha, terutama usaha berskala mikro dan menengah.

Namun faktanya, meskipun saat ini perusahaan berskala besar, maupun berskala kecil mulai menggunakan media sosial sebagai salah satu strategi promosi dan sebagai salah satu akses untuk mendekatkan diri kepada konsumen, jumlah penggunaannya masih terbilang cukup terbatas. pemanfaatan media sosial sebagai media pemasaran masih belum maksimal jika dibandingkan dengan pertumbuhan penggunaan internet yang meningkat drastis. Diperkirakan hanya $30 \%$ pelaku usaha di Indonesia yang memanfaatkan media sosial atau instrumen digital dalam mengembangkan usahanya. Hal ini menggambarkan bahwa konsep pemasaran digital masih bisa berkembang lebih besar. Konsep pemasaran yang berbasis pada teknologi digital harus bisa lebih dimanfaatkan oleh usaha berskala mikro agar dapat berkembang menjadi pusat kekuatan ekonomi Indonesia. UMKM harus benar-benar mampu memanfaatkan media sosial sebagai salah satu alternatif strategi promosi atau pemasaran, karena media sosial memiliki potensi meningkatkan penjualan produk UMKM, dan untuk tahap selanjutnya diikuti dengan peningkatan proses produksi dan produktivitas UMKM.

Menurut Wardhana (2015), mengemukakan bahwa strategi pemasaran yang berbasis internet memiliki pengaruh hingga 78\% terhadap keunggulan bersaing UMKM dalam memasarkan produknya ke khalayak umum. Strategi yang dimaksud yaitu sebagai berikut: 1) Ketersediaan informasi terkait produk yang ditawarkan serta panduan produk. 2) Ketersediaan gambar- gambar seperti foto produk atau ilustrasi produk. 3) Ketersediaan video yang mampu memberikan gambaran produk atau memberikan representasi terkait kualitas produk. 4) Ketersediaan lampiran dokumen- dokumen yang berisi informasi dalam berbagai format. 5) Ketersediaan komunikasi online yang secara langsung menghubungkan konsumen dengan pihak perusahaan. 6) Ketersediaan alat transaksi dan variasi media pembayaran yang memudahkan konsumen dalam melakukan proses pembayaran. 7) Ketersediaan bantuan dan layanan konsumen. 8) Ketersediaan dukungan opini terkait produk secara online. 9) Ketersediaan fitur atau tampilan testimonial. 10)Ketersediaan catatan pengunjung. 11) Ketersediaan penawaran khusus. 12)Ketersediaan sajian informasi terbaru melalui SMS blog. 13)Kemudahan pencarian produk. 14)Kemampuan penguatan citra merek yang diterima oleh oleh konsumen. 15) Kemampuan mengidentifikasi dan menarik pelanggan baru.

Oleh karena itu, media sosial memiliki potensi besar dalam membantu dan meningkatkan pendapatan dari para pelaku usaha baik yang berskala kecil, berskala menengah, maupun berskala besar. Aplikasi pemasaran melalui media sosial menyediakan pesan instan hingga situs jejaring sosial yang menawarkan pengguna untuk berhubungan, berkomunikasi, dan berinteraksi antara satu sama lain. Kemudahan- kemudahan yang disediakan dalam pemasaran digital bertujuan untuk meraih simpati masyarakat melalui pengedaran informasi online terkait pengalaman konsumen dalam mengonsumsi produk atau merek tertentu, hal ini merupakan tujuan utama untuk memperoleh kepercayaan pelanggan dalam memastikan kualitas suatu produk.

\section{Minimnya Pemahaman Pelaku UMKM Dalam Pemanfaatan Media Sosial}

Berdasarkan hasil pengamatan dan wawancara saya di beberapa UMKM yang berada di Kecamatan Ambulu, banyak pelaku UMKM yang belum memanfaatkan sosial media secara optimal sebagai salah satu tempat pemasaran produk dan juga sebagai salah satu strategi promosi. Bahkan beberapa dari mereka tidak menggunakan sosial media sebagai tempat pemasaran digital yang saat ini sangat digandrungi oleh kebanyakan orang, mereka masih menggunakan sistem kuno dalam mengelola usahanya. Dan mereka yang sudah menggunakan sosial media pun tidak benar- benar menguasai sistem pemasaran berbasis digital. Para pelaku usaha mikro yang saya amati kebanyakan hanya menggunakan Facebook, Whatsapp, dan sangat sedikit yang menggunakan Instagram. Sampai saat ini, saya masih menemukan dua usaha mikro yang mulai merintis bisnis melalui platform Shopee. Dua usaha mikro yang membuka toko di Shopee tersebut memiliki bidang usaha yang berbeda. Usaha Mikro yang pertama bernama Toko Lindiamond yang fokus dalam bidang fashion dan skincare, mereka juga aktif di Instagram, Facebook, dan Whatsapp. Sementara itu, usaha yang kedua bernama Toko Makmur Jaya yang fokus pada bidang usaha perlengkapan rumah tangga. Namun berdasarkan pengamatan saya, 
Toko Makmur Jaya hanya menggunakan Platform Shopee dalam mempublikasikan produknya. Sisanya hanya aktif di Facebook dan Whatsapp. Para pelaku usaha mikro yang menggunakan sistem pemasaran berbasis digital pun masih menggunakan perlengkapan ala kadarnya, berbeda dengan para pelaku usaha berskala besar yang menggunakan fasilitas- fasilitas mewah dalam proses dokumentasi. Sebagian besar para pelaku usaha mikro hanya menggunakan kamera smarthphone dalam proses pengambilan gambar, sehingga hasil yang didapatkan masih memiliki resolusi rendah. Hal ini berkaitan dalam menarik perhatian konsumen, dimana sebagian besar konsumen tertarik dengan melihat tampilan gambar suatu produk. Tampilan gambar yang semakin menarik akan lebih membawa banyak konsumen sehingga dapat meningkatkan penghasilan UMKM.

Terlihat jelas bahwa terdapat kesenjangan dalam penggunaan teknologi di masyarakat desa. Kesenjangan digital secara umum dapat didefinisikan sebagai suatu kondisi dimana ada perbedaan antar individu dalam konteks pemanfaatan teknologi. Konsep kesenjangan digital sudah banyak dikemukakan oleh berbagai ahli dan bahkan lembaga yang fokus pada permasalahan kesenjangan digital (digital divide), salah satunya yang dikemukakan oleh Organization for Economic Co- Operation Development (OECD) (2001) yang mendefinisikan kesenjangan digital sebagai kesenjangan yang terjadi diantara tingkat individu, rumah tangga, dan area geografis yang memiliki tingkat pertumbuhan sosial ekonomi berbeda, berdasarkan kesempatan dalam mengakses teknologi informasi dan komunikasi. Dengan kata lain kesenjangan digital yang dimaksud adalah suatu kondisi dimana terdapat perbedaan dalam hal mengakses teknologi informasi dan komunikasi atau kesenjangan aksesbilitas yang terjadi pada individu, rumah tangga dan area geografis yang memiliki tingkat sosial ekonomi berbeda. Konsep serupa juga disampaikan oleh Smith (2015), yang mendefinisikan kesenjangan digital sebagai suatu kesenjangan antara masyarakat yang telah dan belum menggunakan Teknologi Informasi dan Komunikasi (TIK), dimana terdapat perbedaan atau gap antara individu satu dengan individu lainnya dalam hal kepemilikan atau hak mengakses teknologi informasi dan komunikasi. Definisi kesenjangan digital tidak hanya tentang perbedaan akses atau minimnya penggunaan teknologi pada setiap individu, namun juga terkait dengan kemampuan dalam memaksimalkan pemanfaatan teknologi. Seiring berkembangnya teknologi, terminologi terhadap kesenjangan akses digital juga terus mengalami perkembangan. Kesenjangan teknologi dapat disebabkan dari berbagai faktor seperi usia, jenis kelamin, penghasilan, pendidikan, dan juga dapat dilihat dari aspek dala mengakses teknologi itu sendiri, seperti motivasi mengakses (Motivational Access), kemampuan mengakses (Skill Access), perangkat teknologi (Material Access), dan penggunaan atau pemanfaatan teknologi (Usage).

Motivational access dapat didefinisikan sebagai ketidaktahuan seseorang terhadap teknologi baru. Pengalaman yang kurang dalam menggunakan teknologi digital mengarah pada motivasi seseorang dalam menggunakan teknologi, yang nantinya mempengaruhi keputusan seseorang dalam membeli peralatan elektronik atau bahkan tidak melanjutkan akses penggunaan internet. Saat ini kesenjangan digital yang disebabkan oleh motivational access sangat sedikit ditemui pada kelompok remaja, namun masih sering ditemui pada kelompok paruh baya terutama laki- laki. Hal ini berbeda lagi jika dilihat berdasarkan status sosial seseorang dan penghasilan atau latar belakang pendidikan seseorang. Laki- laki paruh baya di daerah desa cenderung tidak memiliki latar belakang pendidikan yang bagus, mereka juga tidak memiliki penghasilan yang tinggi. Pada umumnya, pasangan paruh baya di daerah desa hanya memiliki satu smartphone yang digunakan secara bergantian, smartphone yang digunakan pun masih tergolong jadul. Selain itu, kebanyakan alat elektronik yang digunakan oleh remaja desa yaitu smarthphone, sedikit dari merekayng memiliki laptop atau komputer di rumah. Misalnya di daerah tempat tinggal saya, dimana hanya saya seorang pelajar yang memiliki laptop. Kesenjangan yang diakibatkan oleh motivational access bukanlah suatu hambatan penting saat ini, karena perkembagan teknologi sekarang ini menawarkan harga yang relatif terjangkau bagi masyarakat berpendapatan rendah sekalipun.

Skill access diartikan sebagai kesenjangan teknologi berdasarkan perbedaan kemampuan seseorang dalam mengoperasikan teknologi beserta perangkat lunak (software) dan perangkat keras (hardware). Kemampuan seseorang dalam mengakses dan mengeksplor teknologi berbeda- beda, tergantung pada kebutuhan dan proses belajar dari setiap individu. Dalam skill 
access terdapat perbedaan skill, yang dibedakan berdasarkan kemampuan dari setiap individu. Yang pertama, operational skills yaitu kemampuan dalam mengoperasikan internet beserta perangkat lunak (software) dan perangkat keras (hardware). Yang kedua, formal skills yaitu kemapuan dalam menangani struktur khusus media digital seperti menu dan hyperlink. Yang ketiga adalah information skills, yaitu kemampuan yang dibutuhkan untuk menemukan, memilih, dan mengevaluasi informasi melalui sumber dari komputer dan jaringannya sesuai pertanyaan dan kebutuhan. Dan yang terakhir yaitu strategic skills yaitu kemampuan dalam menggunakan perangkat elektronik dan sumber informasi sebagai suatu sarana untuk tujuan tertentu.

Material access dapat didefinisikan sebagai salah satu penyebab kesenjangan digital yang menunjukkan belum terpenuhinya aksesibilitas yang diperoleh seseorang dari teknologi agar dapat terhubung ke internet (Ragnedda, 2017). Perbedaan akses yang didapat berkaitan dengan bagaimana individu memperoleh akses terhadap ketersediaan hardware, software, jaringan, serta penggunaan alat- alat teknologi dan aplikasinya.

Pembangunan di wilayah desa yang kurang maksimal juga menjadi faktor utama dalam kesenjangan penggunaan teknologi. Pada umumnya, masyarakat desa kurang melek terhadap perkembangan teknologi. Tanpa mereka sadari, teknologi mampu memberikan kenyamanan bagi masyarakat. Jika dibandingkan dengan masyarakat kota, masyarakat desa masih tertinggal jauh dalam aspek pembangunan. Hal ini yang melatarbelakangi masyarakat desa masih terlalu kuno dan tertinggal oleh perkembangan zaman. Misalnya dalam bidang bisnis, masyarakat desa cenderung tidak menggunakan media sosial dalam memasarkan usahanya. Mereka hanya mengandalkan cara kuno dengan menjajakan dagangannya secara offline, cara ini cenderung dilauka oleh mereka para pelaku usaha mikro yang sudah memasuki usia paruh baya atau bahkan mereka yang sudah memasuki usia lajut. Para pelaku usaha mikro di daerah desa hanya mengandalkan penghasilannya dari hasil penjualan offline. Ini menggambarkan bahwa usia dapat menghalangi seseorang dalam penggunaan teknologi, bagi merekayng sudah memasuki usia lanjut merasa bahwa mereka tidak membutuhkan teknologi informasi (media sosial seperti facebook, whatsapp, dan semacamnya) dalam hidupnya, sehingga mereka merasa tidak perlu belajar untuk mengoperasikan teknologi. Mereka masih belum sadar akan manfaat teknologi informasi dalam mendorong perkembangan suatu usaha. Namun tidak menutup kemungkinan bagi mereka yang sudah mulai membuka usaha sejak usia dini untuk memanfaatkan teknologi dalam mengembangkan usahanya. Dari data yang saya peroleh selama pengamatan, pelaku usaha mikro yang menggunakan teknologi dalam mengembangkan bisnisnya didominasi oleh usia remaja hingga usia 30-an.

Penduduk desa didominasi oleh mereka yang memiliki pendidikan dan penghasilan rendah. Tidak heran jika terjadi kesenjangan digital dalam masyarakat desa, letak geografis yang kurang mendukung juga menjadi dasar terjadinya ketidakmerataan pembangunan di wilayah desa. Masyarakat desa yang masih memegang teguh tradisi menjadikan tradisi sebagai salah satu pedoman dalam menjalankan kehidupannya. Sebagian besar masyarakat desa juga masih memandang perempuan hanya sebagai ibu rumah tangga. Dimana pada akhirnya, perempuan akan kembali ke dapur dan hanya akan mengurus anak dan suaminya di rumah, setinggi apapun pendidikan perempuan tersebut. Masih terdapat perbedaan antara laki- laki dan perempuan dalam mengejar karir. Laki- laki dapat secara penuh mencurahkan perhatiannya kepada karirnya, namun berbeda dengan perempuan yang juga harus memikirkan keluarganya sebelum memikirkan karirnya. Hal ini juga dirasakan oleh saudari Roziyatun Nikmah yang merupakan salah satu seorang pelaku usaha mikro dalam wawancara, terkait penggunaan media sosial sebagai salah satu strategi promosi UMKM. Saudari Roziyatun Nikmah mengaku belum menggunakan media sosial sebagai sistem pemasaran berbasis digital, beliau mengaku masih belum sempat untuk mengambangkan usahanya ke dalam sistem digital hal ini dilatarbelakangi oleh kesibukannya sebagai ibu rumah tangga yang memiliki kewajiban untuk mengurus suami dan anak- anaknya. Saudari roziyatun nikmah menjelaskan bahwa beliau tidak memiliki cukup tenaga untuk menjalankan bisnis secara online disamping mengurus keluarga. Hal ini menjelaskan bahwa terdapat hambatan bagi perempuan untuk mengejar karir.

Definisi kesenjangan dalam penggunaan teknologi terus berkembang seiring berkembangnya pola interksi dan pola perilaku masyarakat itu sendiri. Masyarakat merupakan makhluk 
sosial yang bersifat dinamis, sehingga diperlukan pemahaman secara menyeluruh dalam mengamati pola perilaku masyarakat. Setiap individu memiliki perbedaan keterbatasan dalam mengakses teknolologi informasi. Begitu pula para pelaku usaha berskala mikro yang ada di daerah Kecamatan Ambulu, para pelaku usaha mikro memiliki alasan tersendiri untuk tidak memanfaatkan media sosial sebagai salah satu strategi promosi. Salah satu pelaku usaha mikro di bidang makanan yang ada di daerah Ambulu, yaitu saudari Sulis yang merupakan pedagang seblak menyatakan bahwa dalam menjalankan usahanya saudari Sulis tidak memanfaatkan media sosial secara maksimal karena keterbatasan skill dalam mengoperasikan teknologi. Saudari Sulis hanya menggunakan whatsapp dan facebook sebagai media pemasaran digital,, selain minimnya skill dalam mengoperasikan media sosial, kurangnya tenaga dalam proses pelayanan juga menjadi hambatan tersendiri. Meskipun hanya melakukan promosi di platform facebook dan whatsapp, sebak sulis selalu dibanjiri pelanggan. Oleh karena itu, saudari sulis tidak memiliki keinginan untuk melakukan pemasaran digital di platform lain.

Tanpa disadari pula usia juga menjadi alat ukur kreativitas para pelaku usaha dalam menjalankan bisnisnya. Pada umumnya, individu dalam tahap usia produktif lebih tertarik untuk mengikuti tren sehingga mereka yang berada pada usia produktif terpacu untuk mempelajari tren yang kemudian akan diterapkan dalam menjalankan kehidupannya. Begitu pula dalam menjalankan usahanya, bagi pelaku usaha yang berada pada usia produktif akan mempelajari tren penjualan dan tren promosi yang sedang digeluti oleh masyarakat saat ini. Dibutuhkan kreativitas dan kepekaan terhadap lingkungan sekitar untuk menjalankan usaha berbasis digital agar mampu bersaing dengan usaha lain. Pelaku usaha yang berada pada usia poduktif akan melakukan penelitian secara menyeluruh sebelum memulai usahanya, selain itu usia produktif cenderung memiliki ambisi yang kuat jika dibandingkan dengan mereka yang sudah memasuki usia paruh baya atau bahkan mereka yang sudh memasuki usia lanjut. Sehingga jika itarik garis besarnyamaka usia juga memengaruh kesuksesan seseorang dalam menjalankan suatu usaha.

\section{KESIMPULAN}

Media Sosial memiliki peranan penting dalam meningkatkan penjualan UMKM. Namun faktanya, masih sedikit pelaku usaha berskala mikro yang memanfaatkan media sosial sebagai sistem pemasaran berbasis digital. Jika dibandingkan dengan pengguna internet yang semakin meningkat setiap tahunnya, penggunaan media sosial sebagai media pemasaran digital dalam bidang bisnis masih tergolong sedikit. Hal ini dilatar belakangi oleh adanya kapabilitas dalam mengakses teknologi sehingga sedikit pelaku usaha yang menggunakan sistem pemasaran digital dalam mengembangkan usahanya. Perbedaan akses tersebut disebabkan oleh beberapa faktor seperti pendidikan, penghasilan, jenis kelamin, usia, area geografis, dan semacamnya. Media sosial memiliki peranan penting dalam meningkatkan pendapatan UMKM. Jika para pelaku usaha mikro dapat memanfaatkan teknologi secara maksimal maka dapat dipastikan pertumbuhan ekonomi di Indonesia juga akan membaik. UMKM merupakan pondasi ekonomi bangsa Indonesia sehingga memiliki peran penting dalam mendongkrak perekonomian Bangsa Indonesia. Oleh karena itu, perlu bagi kita untuk mendukung perekonomian UMKM melalui pemanfaatan Teknologi Informasi. Sekarang ini, sudah banyak tersedia berbagai platform belanja online dengan berbagai kemudahan yang ditawarkan untuk membantu masyarakat dalam melakukan aktivitas jual beli secara online serta kemudahan dalam melakukan transaksi.

\section{DAFTAR PUSTAKA}

Akhmad, Khabib Alia. 2015. "Pemanfaatan Media Sosial bagi Pengembangan Pemasaran UMKM (Studi Deskriptif Kualitatif pada Distro di Kota Surakarta)." Duta.com 45-54.

Badri, Muhammad. 2016. "Pembangunan Pedesaan Berbasis Teknologi Informasi Dan Komunikasi (Studi pada Gerakan Desa Membangun)." Jurnal Risalah 62-73.

Febriyantoro, Mohamad Trio. 2018. "Debby Arisandi Halaman 61 dari 76 JMD." Jurnal Manajemen Dewantara 61-76.

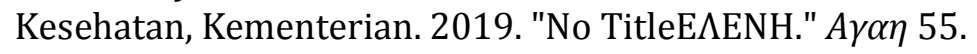

Maslan, Andi. 2014. "Analisis Faktor-Faktor Mempengaruhi Kesenjangan Digital Studi Kasus Barelang (Batam, Rempang Dan Galang) Kepulauan Riau." CBIS Journal 1-9. 
Permana, Silvester Dian Handy. 2019. "Pemanfaatan Sosial Media sebagai Strategi Promosi bagi Sustainability Bisnis UMKM." ETHOS (Jurnal Penelitian dan Pengabdian) 163-169.

Purwana, Dedi. 2017. "Pemanfaatan Digital Marketing Bagi Usaha Mikro, Kecil, Dan Menengah (UMKM) Di Kelurahan Malaka Sari, Duren Sawit." Jurnal Pemberdayaan Masyarakat Madani (JPMM) 1-17.

Putri, Whopy Chidya. 2018. "Kesenjangan Digital Pada Kalangan Remaja Whopy Chidya Putri 1." 1-11.

Suci, Yuli Rahmini. 2017. "Perbedaan Usaha Mikro , Kecil , dan Menengah Perkembangan UMKM di Indonesia." Jurnal Ilmiah Cano Ekonomos 51-58.

Sudrajat, Dadang. 2019. "Ragam Penelitian Kualitatif." 